\title{
砂浜の侵食域・堆積域における地形断面の 季節変化についての一考察
}

\begin{abstract}
村上亘*
要 旨本研究では, 侵食域と堆積域という異なる傾向にある区域が隣接する砂浜における地形断面 の季節変化を, 月ごとの地形断面測量により求め, 地形断面図上の断面積の変化を指標として, 調査期間を通したそれぞれの区域の変化パターンの違いを明らかにすることを目的とした。調 査地は仙台湾北部，矢本付近の砂浜海岸である。ここは近年の砂浜侵食防止を目的とした数基 のヘッドランドの建設により，これらに挟まれた区間では侵食・堆積の場が微細に反復して生 じている。

調査の結果，砂浜は侵食域・堆積域ともに同じ傾向の季節変化をしていることが認められた。 同時に，堆積量・侵食量がそれぞれの区域での相対的な差が認められ，この事が結果として調 査期間を通したそれぞれの区域の傾向を決定している事が示唆された。

キーワード 砂浜海岸, ヘッドランド (突堤), 侵食域, 堆積域, 地形断面測量, 地形変化, 矢本 海浜緑地
\end{abstract}

\section{I.はじめに}

砂浜地形は，波浪および土砂供給といつた与えら れた条件の下で，程度の差こそあれ，絶えず変化し ながら長い年月をかけて平衡状態へと移行する。そ して，与えられた条件が変化すると直ちに侵食ある いは堆積傾向の変化を示し，新たな平衡状態へと移 行する（砂村, 1996）。

近年，防波堤や離岸堤といつた海岸構造物の設置 による条件の変化が砂浜地形に急激な変化をもたら している(宇多，1990)。とくに，それらによって限 定された区間の砂浜では，侵食傾向の区域(侵食域) と堆積傾向の区域（堆積域）が隣接して生じている ことが多くの報告事例から明らかになっている（例 えば宇多ほか，1986；宇多ほか，1988；宇多・野口， 1994 など)。

しかしこれまでの報告は，空中写真を用いた汀
線 $^{1)}$ 位置の経年変化の判読を通して示されたもので あるため，侵食域・堆積域のより短期的な変化，例 えば季節変化，あるいは台風の通過といったより一 時的な変化は明らかにされていない。

本報告では，宮城県矢本町の砂浜海岸に建設され た数基のへッドランド (突堤) で区切られた砂浜の 区間内に生じた侵食域・堆積域それぞれの 1994 年 3 〜12 月までの季節変化の実態を, 地形断面測量によ りもとめ，互いの相違点について考察を行った。

\section{II. 対象地域の地形概観}

調査地は宮城県桃生郡矢本町の矢本海浜緑地に隣 接する緩斜海岸（茂木，1963）に分類される砂浜海 岸である(第 1 図)。この海岸の東方約 $4 \mathrm{~km}$ には石 巻工業港が，さらに東方約 $4 \mathrm{~km}$ には旧北上川の河 ロが位置している。また，調査地の西方約 $2 \mathrm{~km}$ 地点 には鳴瀬川の河口が位置している。さらに西方には,

\footnotetext{
* 森林総合研究所東北支所 干 020-0123 岩手県盛岡市下厨川字鍋屋敷 92-25
} 


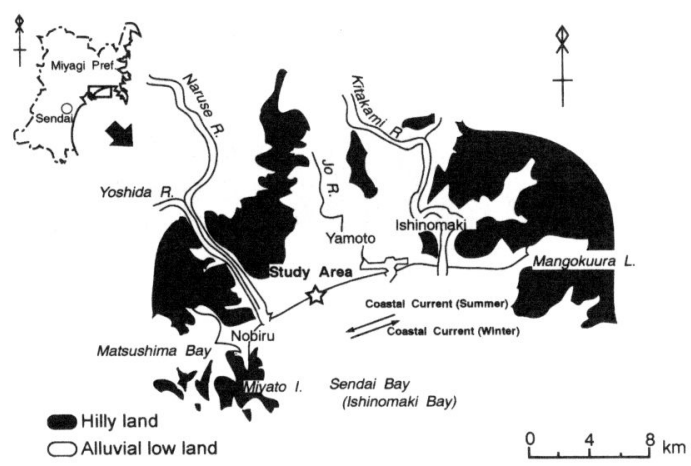

第 1 図 調査地域概略図

Fig. 1 Study area

八島（1998）が近世の北上川の河道改修による多量 の土砂の石巻湾への流入が原因で急速な砂浜の拡大 が起こったと推定した野蒜洲崎浜海岸が位置してい る。

本調査地は旧北上川の河口と野祘との間に位置す るが，これまでに急速な汀線変化の報告はなされて いない。しかし, 少なくとも 1965 年以降は防波堤や 導流堤などの海岸構造物の設置による沿岸漂砂の滞 留や人為による河川の運搬土砂量の減少により砂浜 は侵食傾向にあり(松本，1994）, 現在は侵食防止の ために後述するへッドランドなどの土木工事が行わ れている。

この海岸では夏季には北東から南西方向に, 冬季 には南西から北東方向に海岸とほほ平行な沿岸流が 卓越する (石巻港湾事務所，1994）。調査地の砂浜に は侵食を防ぐ目的でヘッドランドが約 $1,000 \mathrm{~m}$ 間隔 で 5 基建設されており，調查区間は東側から数えて 4 基目と 5 基目のへッドランドに挟まれている (第 2 図, 写真 1)。4 基目と 5 基目のヘッドランドは 約 $1,000 \mathrm{~m}$ 隔てて建設されており，それぞれ海側に 約 $150 \mathrm{~m}$ 突出している。

\section{III. 研究方法}

砂浜の季節ごとの地形断面形および汀線位置の変 化を明らかにするために, 次の方法で地形断面測量

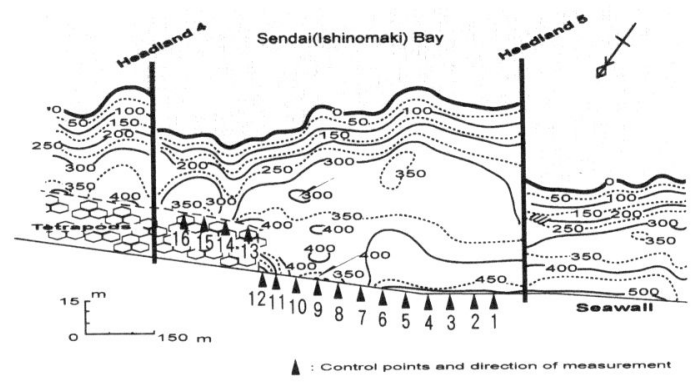

第 2 図 調査区間の 8 月の測量 (等高線) 図（単位 $\mathrm{cm}$ )

Fig. 2 Surveying map of the study section, Aug. 1994 (unit $\mathrm{cm}$ )

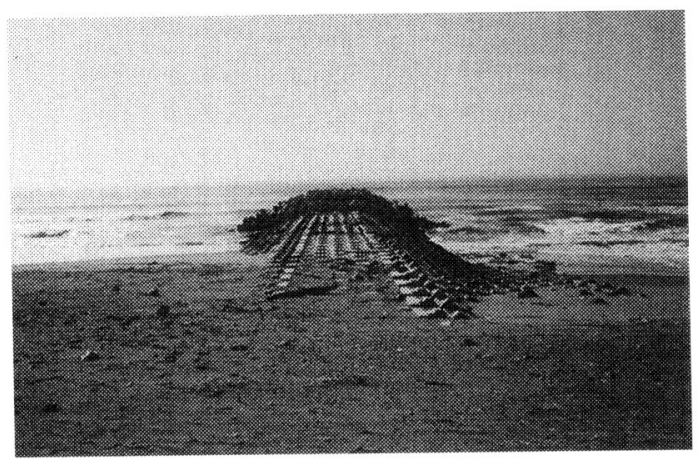

写真 1 調査地域に建設されているへッドランド 5 Photo. 1 Headland 5 in the study area

を行った。

まず，調查地域内にある汀線とほぼ平行に伸びる 海抜約 $6 \mathrm{~m}$ の防潮堤を基準とし, 海岸線にほぼ直交 し，互いに平行な測線を約 $50 \mathrm{~m}$ 間隔に 16 本設定し

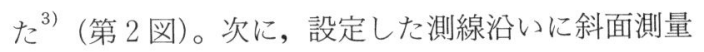
器を用いて $2 \mathrm{~m}$ 間隔で傾斜角 $\theta$ を計測し, 垂直位置 (高さ：H）抢よび水平位置（距離：L）をもとめた (第 3 図)。測量に斜面測量器を用いたのは潮位変化 との関係上，できるだけ短時間に一連の測量を終了 させる必要があったためである。この斜面測量器を 使用することによる測量の精度については, 同時に 実施した数本のオートレベルを用いた測量結果との 比較から，その誤差は水平方向で $1 \mathrm{~m}$ あたり \pm 1 $\mathrm{cm}$, 垂直方向で $1 \mathrm{~m}$ あたり $1.5 \mathrm{~cm}$ であった。この 


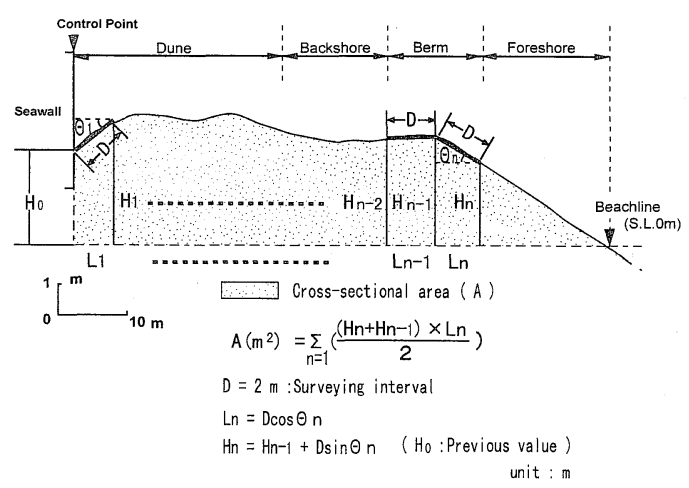

第 3 図調查地域の地形断面模式図 測量方法扔よびそれに基づく断面積の計算 式を示す。

Fig. 3 Morphological cross section of sand beach

誤差は計測距離が長くなるほど大きくなるが，垂直 方向は砂浜の高度が $5 \mathrm{~m}$ 程度のため, 誤差も最大 15 $\mathrm{cm}$ 程度である。一方, 水平方向については基準点か らの距離が最大 $100 \mathrm{~m}$ のため, 誤差も $2 \mathrm{~m}$ 近く生じ ることになる。しかし, 調查地の砂浜は汀線付近で 一ヶ月で少なくとも $5 \mathrm{~m}$, 平均で $10 \mathrm{~m}$ 近く水平方向 に変化するため, 次章で述べる砂浜の侵食・堆積を もとめるにあたっては，水平方向，垂直方向とも大 きな支障をきたすことはないと考える。

測量は 1994 年 3 月から 12 月まで毎月行い，その 結果から第 3 図に模式的に示したような測線ごとの 地形断面形を月ごとにもとめた。なお，測量は比較 的天候が穏やかで，日中の潮位が海抜 $0 \mathrm{~m}$ 以下にな る日を選んで $30 \pm 10$ 日の間隔で行った。

\section{IV. 調査結果および考察}

\section{1. 月ごとの砂浜の侵食・堆積の認定方法}

砂浜の侵食・堆積は，汀線位置の変化ではなく堆 積物（土砂）の堆積量および侵食量の変化をもとめ ることにより把握することにした。これは，従来用 いられてきている汀線の位置の水平的な変化による 砂浜の前進・後退距離をもって侵食・堆積を認定す

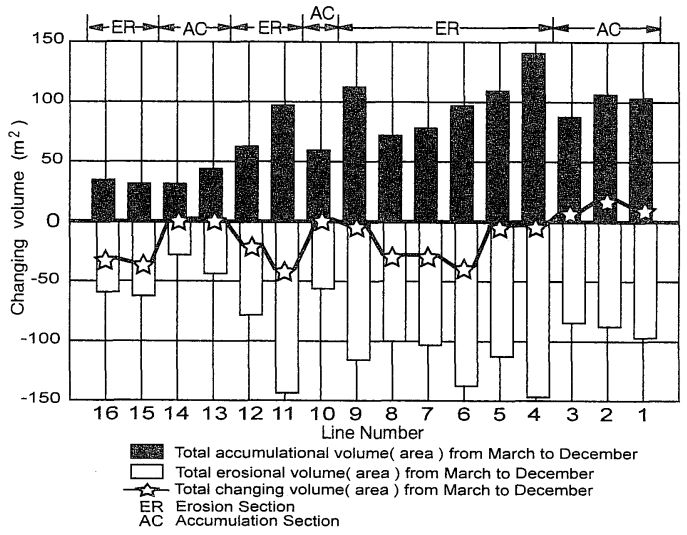

第 4 図調査期間を通した測線ごとの地形断面積の 増減

Fig. 4 Changing rate of the cross-section area on every line from March, 1994 to December, 1994

ることは不適当であると考えたからである。すなわ ち,第 5 図の測線 2 , および測線 7 に代表される月ご との地形変化で示されるように，6月よりも 7 月の 汀線位置はより海側へ前進しているにもかかわらず 前浜上部では削られている部分も見られる。また，8 月は 7 月に比べるとバームの発達が顕著であるにも かかわらず，汀線位置は後退している。このように， 汀線位置の変化は必ずしも砂浜の土砂の侵食・堆積 の状況とは一致しない事例が少なからず認められ る。このため，砂浜の各測線における月ごとの地形 断面図上の断面積をもとめ, その変化を堆積量, 侵 食量の指標として用いることにした。

断面積は, 水平方向は基準点から汀線位置まで,垂 直方向は汀線 (海抜 $0 \mathrm{~m}$ ) を下限とする砂浜表面まで を範囲として，第 3 図で示す方法で計算し，もとめ た。

\section{2. 調査区間内の侵食域・堆積域の区分}

ヘッドランドに挟まれた区間における侵食域・堆 積域は月ごとに変化し，明確に区域を区分すること は困難である。そのため，ここでは便宜的に観測終 了時（12月）の地形断面図上の断面積（土砂量）が 観測開始時 $(3$ 月) よりも増加している測線の区域を 

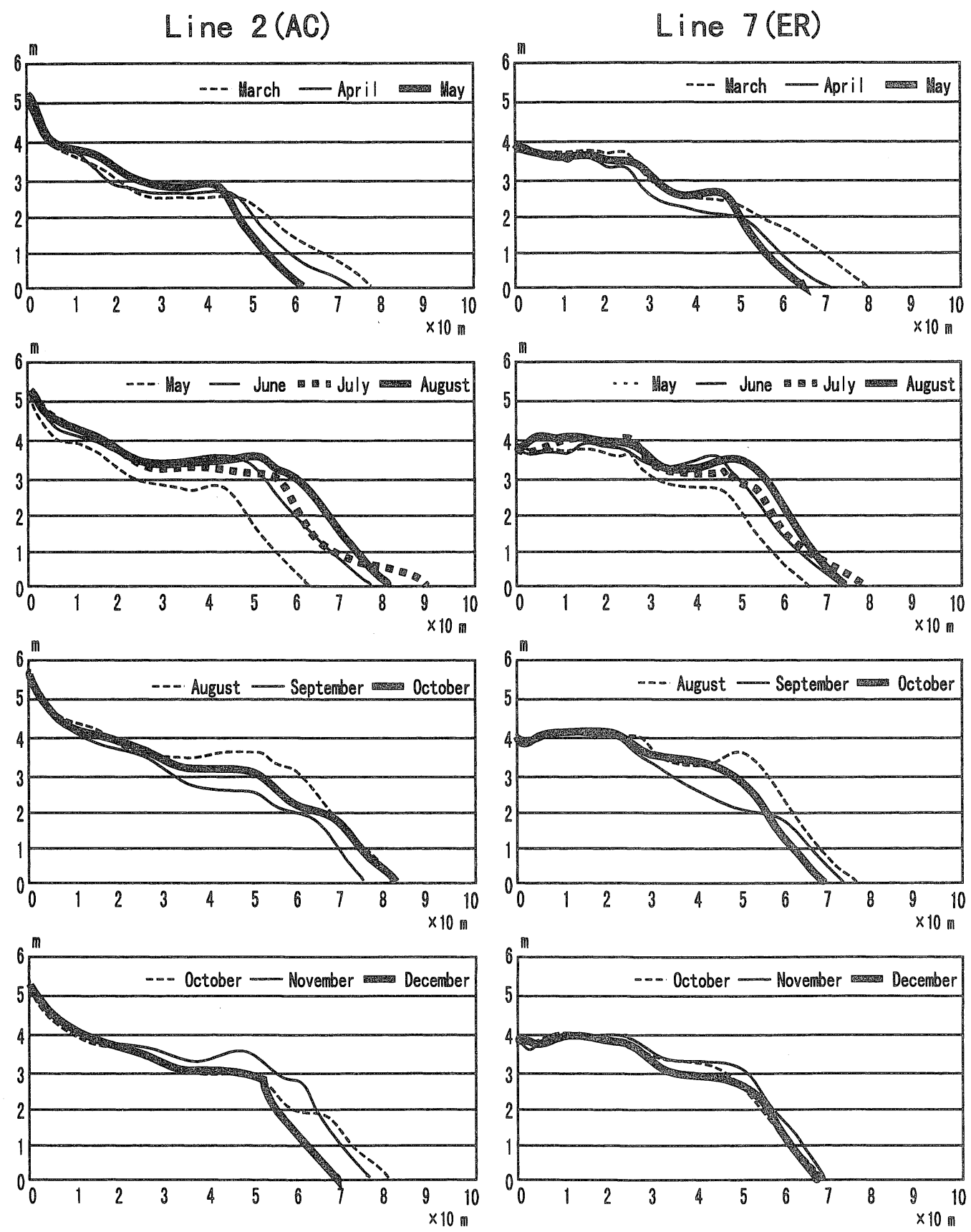

第 5 図 地形断面の変化

Fig. 5 Change of the cross section on line 2 (Accumulation Section) and Line 7 (Erosion Section) 
堆積域，減少している測線の区域を侵食域とするこ とにした。すなわち，調査区間は第 4 図で示すよう に測線 1 から 3 の区域, 測線 10, および測線 13 から 14 の区域が堆積域，測線 4 から 9, 測線 11 から 12 , そして測線 15 から 16 の区域が侵食域となる。

このように堆積域と侵食域は調査区間を通してか なり微細に反復している実態が確認された。また,調 查区間における堆積域の範囲は侵食域の範囲よりも 狭く，堆積量も少ないことが認められた。

\section{3. 砂浜の地形断面形の季節变化}

堆積域，侵食域の地形断面形の月ごとの変化はそ れぞれの区域の典型的な測線である測線 2 (堆積域) および測線 7 (侵食域) の変化を第 5 図に示した。そ れぞれの区域の変化とも，抢掠む㸚以下のようで あった。

3〜4 月 砂浜は区間全域を通して侵食され, 海岸 線は大きく後退した。また，砂浜はバームが消失し， 前浜の傾斜が比較的緩い $\left(3^{\circ} \sim 5^{\circ}\right)$ という特徵があっ た。

4〜6月 バームの発達が見られた。特に 5〜 6月 の期間が顕著であった。

6〜7月この時期，砂浜は若干削られた。これは 波浪が高くなったためと思われる。なお，測量した 多くの測線で前浜上部，バーム付近の侵食が見られ たが，逆に汀線付近では砂の堆積が確認された。

7〜8月 5〜6月の期間と同様にバームの発達が 顕著であった。しかし，多くの場所では汀線が後退 していた。

8〜9月 9 月 12 日に台風 21 号が，19 日には台風 24 号が沿岸を通過した。また，9月の中旬から下旬 にかけては秋雨前線の活動に伴う大雨と高波に見舞 われた。さらに 30 日には調査地域を台風 26 号が直 撃した。これらに伴う波浪は調查地域の砂浜の地形 断面形に大きな影響を与え，調査区間全体にわたっ て砂浜が侵食された ${ }^{4)}$ 。

10〜11月 砂浜は回復傾向にあるが最も堆積が
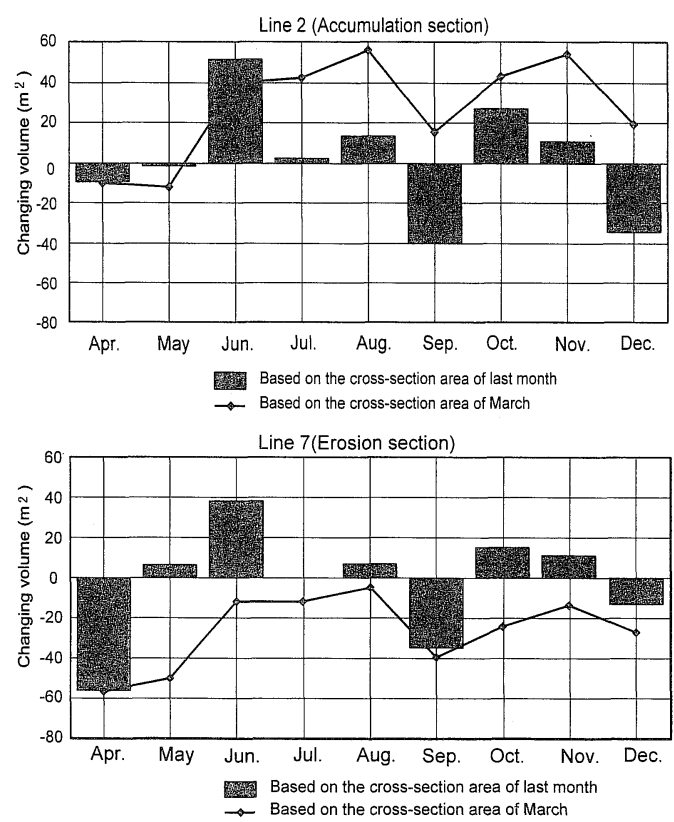

第 6 図 各測線における地形断面積の相対変化

Fig. 6 Relative change of the cross-section area on every line

進行した 8 月の時点の形状には達していなかった。 11〜 12 月 砂浜は再び侵食を受けた。

\section{4. 侵食域・堆積域での土砂量の季節変化}

第 5 図で示した測線 2 と測線 7 の地形断面から, 前月を基準とした地形断面図上の断面積の変化量と 観測を開始した 3 月を基準とした各月の断面積変化 量を表したものが図 6 である。図 6 より以下のこと が示された。

侵食域である測線 7 では，4 月に地形断面積にし て $60 \mathrm{~m}^{2}$ 近く砂浜が 3 月よりも侵食される。そして, 5〜8 月にかけて徐々に回復するが 3 月の土砂量に は達せず, 9 月に再び $35 \mathrm{~m}^{2}$ 以上削られた。その後 10 〜11月に若干の回復はするものの，結果として調査 を終了した 12 月に至るまで砂浜は 3 月の時点の土 砂量を回復することなく推移した。これに対し，堆 積域である測線 2 では, 3〜 5 月にかけて侵食を受け るが,その量は $10 \mathrm{~m}^{2}$ 程度と測線 7 よりも少ない。そ して，6〜8月にかけて，とくに 6 月に $50 \mathrm{~m}^{2}$ 以上の 
土砂が堆積した。その後 9 月に約 $40 \mathrm{~m}^{2}$ ほど侵食さ れたが, 10〜11月に再び土砂の堆積があり, 12 月に は $30 \mathrm{~m}^{2}$ 以上の侵食を受けたものの，基本的には 3 月の頃よりも土砂量が増えた状態で推移した。この ように，測線 2 および測線 7 は，ほぼ同時期に侵食 または堆積作用が起こっていたが，調査期間を通し てみると，測線 2 では堆積量が，測線 7 では侵食量 が相対的に上回ることが認められた。

堆積域・侵食域に区分した他の測線についても,月 ごとの侵食量あるいは堆積量に違いはあるものの, 測線 2 および測線 7 と同じ時期に侵食または堆積の 作用が起っていた。そして，調査期間を通してみる と堆積域に区分した測線では堆積量が, 侵食域とし た測線では侵食量が相対的に上回る傾向が確認され た。このように, 侵食傾向にある区域, 堆積傾向に ある区域は同じ時期に侵食, あるいは堆積の作用が 起こるが，その変化量の相対的な違いにより，その 区域がより長期的に見て侵食域あるいは堆積域とな る可能性が指摘される。

\section{V. ま と め}

ヘッドランドの設置により人為的に生じた砂浜の 侵食域，堆積域において調查期間を通した海岸線の 季節変化を侵食土砂量, 堆積土砂量という観点から とらえた。とくに地形断面上での断面積の変化を指 標に着目して, 砂浜の侵食および堆積の状況を把握 した。

調査から，砂浜において調査期間を通してみた場 合の侵食域あるいは堆積域を設定したが，いずれも 季節ごとに同椂の侵食，堆積といった変化傾向が認 められた。つまり, 砂浜が削られる時は侵食域・堆 積域共に削られ, 砂浜が堆積する時は同じ時期に堆 積していることが示された。また，同じ時期に侵食 あるいは堆積しても, 期間を通してみると, 侵食域 では侵食量が, 堆積域では堆積量が相対的に上回り, そのことが調査期間を通した期間における侵食抒よ
び堆積の傾向を決定づけることが示唆された。なお， これらについては浅海部分の侵食・堆積と合わせて 今後より詳細に議論することが必要であると考えら れる。

\section{謝 辞}

本稿を作成するにあたり，終始ご指導頂いた東北大学 地理学教室の松本秀明先生, 調査に協力して頂き多くの 有益な助言をして頂いた東北大学地理学教室の諸先生 方, 先輩方に心からお礼申し上げます。本稿は 1994 年度 卒業論文の一部であり, 1995 年度東北地理学会春季学術 大会において発表した内容を加筆修正したものである。 (2001年9月 25 日 受理)

\section{注}

1）ここで示される汀線とは波打ち際のことである。 本文では, 砂浜の地形断面図上の断面積を算出する ため, 基準とした防潮堤から計測して海抜 $0 \mathrm{~m}$ と なる場所を汀線位置としている。

2）調查時にはヘッドランド 5 の西側に 6 基目の ヘッドランドの建設が進められていた。

3）測線 13 から 16 については、基準点を防潮堤の海 側に積まれているテトラポッドに設定した。調査期 間中にテトラポッドの移動は見られなかった。

4） 1994 年 10 月 1 日の観察では, ヘッドランド 4 の 東方約 $1 \mathrm{~km}$ 付近では砂浜が消失し, 防潮堤に波が かかる状態であった。

\section{文献}

宇多高明 (1990)：わが国の海岸侵食の現状とその 問題点. 地理, 35-6, 34-43.

宇多高明・住谷廸夫・小林洋三 (1986) : 茨城県にお

ける海浜変形の実態。地形, 7, 141-163.

宇多高明・小林正一・種岡虎男 (1988) : 新潟県市振 海岸における海岸構造物設置に伴う海浜変形。 地形, 9, 35-52.

宇多高明・野口賢二 (1994): 防波堤による沿岸漂砂 の阻止と海食崖からの土砂供給の現象とに起因 する海岸侵食一福島県北部〜宮城県南部の例 一。地形, 15, 129-144.

砂村継夫（1996）：土木工事による海岸地形の変化. 小池一之・太田陽子編：変化する日本の海岸 
一最終間水期から現在まで一。古今畫院，137156.

宮城県石巻港湾事務所（1994）：石巻港湾事務所港

湾調查報告, 添付図。

松本秀明（1994）：仙台湾の砂浜侵食と海岸構造物。

東北大学理学部特定研究報告, 45-53.
茂木昭夫（1963）：日本の海浜型について(沿岸州の 地形学的研究 第 1 報)。地理学評論, $36,245-$ 266

八島邦夫 (1998)：野蒜洲崎浜の急速な地形発達と その要因についての一考察. 季刊地理学, 50 , $329-337$

\section{Seasonal Changes in the Erosion and Accumulation Sections of a Portion of Yamoto Sand Beach, Sendai Bay, Northeast Japan}

\section{Wataru MURAKAMI*}

The monthly cross-section measurement of a sandy beach was carried out from March, 1994 until December, 1994 in order to compare the differences in seasonal changes of the erosion or accumulation section of the beach.

The area investigated is on Yamoto Sand Beach, which faces Sendai Bay, on the northeastern part of Honshu island. Six headlands have been constructed on this beach in recent years, in order to protect it from the coastal erosion. The headlands have been installed at about $1,000 \mathrm{~m}$ intervals, and stick out about $150 \mathrm{~m}$ into the sea. The area investigated was between two headlands. On the sandy beach within these headlands, the line joining the erosion section and accumulation section was clear, because the conveyance of sand by the coastal current was obstructed by the headlands.

The surveying line intersecting with the right angle in the coastline was set up at about 50 $m$ intervals. Along the line, measurements were carried out using a simple surveying instrument.

The results of the measurements are as follows:

(1) It was shown that the same morphological changes were occurring in the erosion and accumulation sections. Both the erosion section and accumulation section accumulate (or erode) in the same amount of time.

(2) The amount of accumulation (or erosion) occurring each month were different in each section. The amount of erosion relatively exceeded the amount of accumulation in the erosion section. On one side of the accumulation section, the amount of accumulation exceeded the amount of erosion.

It was postulated that the relative difference of a small change in the cross-sectional area (sand volume) determined the tendency (erosion or accumulation) of the applicable section during the investigation period.

* Forestry and Forest Products Research Institute, Tohoku Reserch Center, 92-25, Nabeyashiki, Shimokuriyagawa, Morioka 020-0123, Japan 
村上 亘: 砂浜の侵食域・堆積域における地形断面の季節変化

Key words : sand beach, headland, erosion section, accumulation section, cross-section measurement, morphological changes, Yamoto Sand Beach 